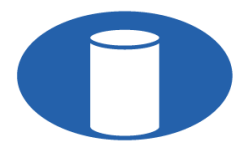

IBRACON Structures and Materials Journal

Revista IBRACON de Estruturas e Materiais

IBRACON

ISSN 1983-4195

ismj.org

ORIGINAL ARTICLE

\title{
Current condition of the exposed concrete façades reinforcement of the Vilanova Artigas building: modern architectural heritage
}

\section{Avaliação do estado de conservação das armaduras das empenas de concreto aparente do edifício Vilanova Artigas: patrimônio cultural da arquitetura moderna}

Adriana de Araujo

Claudia de Andrade Oliveira ${ }^{\mathrm{b}}$ (1)

Tatiana Regina da Silva Simão ${ }^{\text {b,c }}$

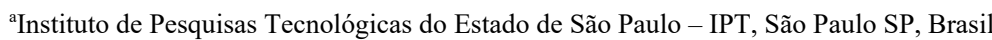

${ }^{b}$ Faculdade de Arquitetura e Urbanismo - FAU, Universidade de São Paulo - USP, São Paulo, SP, Brasil

'Instituto Federal São Paulo - IFSP, São Paulo, SP, Brasil

Received 04 March 2020

Accepted 12 June 2020

\begin{abstract}
The heritage of modern architecture in exposed reinforced concrete has been shown pathological manifestations affecting the structural safety and functionality of the buildings. The manifestations are, primarily, associated with the steel corrosion; however published data obtained from site surveys, on the Brazilian architectural heritage and related to the issue, are still scarce in the literature. Thus, the aim of the study is to assess the current condition of the exposed concrete façades reinforcement of the Vilanova Artigas building, a Brazilian architectural heritage, opened in 1969. Legal restrictions limited the destructive tests and sampling areas. The history of the interventions, environmental aggressiveness and preliminary inspection (in the parent concrete and patch repairs) provided qualified information for analyzing in situ testing results. In the sampling areas physical, chemical and electrochemical tests were carried out. The façades surfaces are naturally porous, irregular, with concrete segregation and corrosion products stains; $24 \%$ of the concrete was replaced with proprietary mortar repair. In patch repairs, the average carbonation depth ranged from 3 to $29 \mathrm{~mm}$, in concrete it ranged from 15 to $30 \mathrm{~mm}$. The reinforcement cover ranged from 8 to $33 \mathrm{~mm}$. Corrosion potential maps, with equipotential lines drawn at $50 \mathrm{mV}$ intervals, indicated the corrosion-prone areas, where there is a concentration of lines with a variation equal to or greater than $150 \mathrm{mV}$. The presence of corrosion products, detected in the visual examination of the reinforcement under the patch repairs, validated the active corrosion state. The rough surface of the concrete, the low cover to depassivated reinforcement and the active corrosion state emphasize the need for monitoring the façades and the urgency of implementing a preventive maintenance plan, along with a conservation project in order to preserve the heritage values of the building.
\end{abstract}

Keywords: heritage conservation, exposed concrete, carbonation, corrosion, electrochemical measurements.

Resumo: O patrimônio da arquitetura moderna de concreto armado aparente tem apresentado manifestações patológicas que afetam a sua segurança estrutural e funcionalidade. As manifestações estão, principalmente, vinculadas à corrosão do aço, entretanto dados de levantamentos de campo, realizados no patrimônio arquitetônico brasileiro e vinculados ao tema, ainda são escassos na literatura. Portanto, o objetivo do estudo é avaliar o estado de conservação das armaduras das empenas de concreto aparente do edifício Vilanova Artigas, patrimônio cultural da arquitetura brasileira, inaugurado em 1969. Restrições legais limitaram os ensaios destrutivos e áreas de amostragem. O histórico de intervenções, a agressividade ambiental e a inspeção preliminar (do concreto original e das áreas recuperadas com argamassa de reparo) compuseram a base para a análise dos resultados. Nas áreas de amostragem foram feitos ensaios físicos, químicos e eletroquímicos. A superfície do concreto é naturalmente porosa, irregular, com segregação e manchas de produtos de corrosão; $24 \%$ do concreto foi substituído por argamassa de reparo. Nos reparos a profundidade média de carbonatação variou de 3 a 29 mm, no concreto variou de 15 a $30 \mathrm{~mm}$. O cobrimento da armadura variou de 8 a $33 \mathrm{~mm}$. Mapas de potencial de

Corresponding author: Tatiana Regina da Silva Simão. E-mail: simao.tatiana@usp.br

Financial support: The Getty Foundation (Keeping It Modern architectural conservation grant), IPT - Institute for Technological Research and IFSP - Federal Institute of São Paulo.

Conflict of interest: Nothing to declare.

This is an Open Access article distributed under the terms of the Creative Commons Attribution License, which permits unrestricted use, distribution, and reproduction in any medium, provided the original work is properly cited. 
corrosão, com linhas equipotenciais traçadas em intervalos de $50 \mathrm{mV}$, indicaram as regiões mais propensas à corrosão onde há concentração de linhas com variação igual ou superior a $150 \mathrm{mV}$. O estado ativo da corrosão foi confirmado pela presença de produtos de corrosão, detectados no exame visual das armaduras sob a argamassa de reparo. $\mathrm{O}$ aspecto irregular da superfície do concreto, o baixo cobrimento da armadura - já despassivada - e o estado de corrosão ativo evidenciam a necessidade de monitoramento das empenas e a urgência da implementação de um plano de manutenção preventiva, combinado a um projeto de conservação para a salvaguarda dos valores patrimoniais do edifício.

Palavras-chave: conservação do patrimônio, concreto aparente, carbonatação, corrosão, medidas eletroquímicas.

How to cite: A. Araujo, C. A. Oliveira, and T. R. S. Simão, "Current condition of the exposed concrete façades reinforcement of the Vilanova Artigas building: modern architectural heritage," Rev. IBRACON Estrut. Mater., vol. 14, no. 1, e14113, 2021, https://doi.org/10.1590/S198341952021000100013

\section{INTRODUCTION}

Samples of the heritage of modern architecture in exposed reinforced concrete, built in the second half of the 20th century, have been shown pathological manifestations affecting the structural safety and functionality of the buildings. The scarcity of systemic studies on the major degradation processes that affect them - corrosion of reinforcement, associated to the lack of deeper knowledge about these buildings, have resulted in unsuccessful interventions, with patch repairs made by using the conventional process adopted in engineering, which mischaracterize the architectural surfaces to be preserved [1].

In Brazil, the preservation of the architectural heritage has been consolidating as an academic field of research and professional practice over the last few decades. Several research centers and laboratories, both among the traditional ones and the ones recently established, have promoted the approach of the several agents involved in preservation of the buildings, providing a multidisciplinary and multidimensional approach.

In spite of the consistent contributions of the abovementioned research centers and laboratories, in addition to the significant production of heritage-oriented graduate programs at universities throughout the country, the researches on the materiality of the built heritage are aimed, in their most part, to the colonial, baroque, eclectic, art noveau, and art décor architectures. Although some groups are focusing their studies to the modern architecture materials, there are still scarce published works on the review of interventions in exposed reinforced concrete in terms of the methodological aspect and impact on the heritage values [2]-[6], as well as experimental researches [7], [8] that relate the concrete and patch repair and finish mortar technologies to the conservation of these structures.

In the international scenario, professionals working in research and practice of patch repair of concrete of the modern architecture already discussed, in the end of 1990s, the corrosion of reinforcements of these structures, as indicated by the papers published in the proceedings entitled "The fair face of concrete" of the Documentation and conservation of buildings, sites and neighborhoods of the Modern Movement - Docomomo International Seminar [9]. The articles express the tacit knowledge acquired in restoration, especially for buildings constructed after World War II. The interventions made in the 1980s and 1990s, based on the current engineering practices, were proved as ineffective, both technically and esthetically, according to studies reported in several articles [10]-[13].

In Brazil, despite the significant collection of modern architecture concrete structures, the discussion about the practice of conservation of the exposed reinforced concrete has not been consolidated yet, even that we can find qualified forums in the Docomomo Brasil Seminars - and in the Regional Chapters Seminars - covering the preservation of this architecture.

A review of the recent bibliography [14] on the conservation of exposed concrete in modernist buildings points the lack of researches about long-term performance of patch repairs, and that the existing assessments of the patch repairs are based on laboratory analyses, which are far from the actual performance of these repairs.

A phenomenon known and checked in the practice is the electrochemical incompatibility between repair material and concrete, described by Gu et al. [15] as a unbalance of the electrochemical potential between several sections of the reinforcement, caused by differences between the aqueous phases (in repair and concrete). This phenomenon may affect the exposed concrete of modern architecture buildings due to their specific characteristics (concrete totally carbonated, carbonation front reaching the reinforcement, high electric resistivity, variation of the reinforcement covering, among others), starting a corrosive process in the areas adjacent to the patch repair. Also, in spite of the scientific and technological mastering of the corrosion mechanisms, there are few studies reported in the literature about exposed concrete buildings, with 50 -year service, presenting history of corrosion caused by carbonation of the concrete cover [16]-[19]. 
Within this context, this study has the aim of assessing the current condition of the exposed concrete façades reinforcement of Vilanova Artigas building, an icon of the Brazilian modern architectural heritage, opened in 1969. The investigation carried out had the purpose of deepening the knowledge of the structure and providing data to the future conservation plan for the building.

\section{VILANOVA ARTIGAS BUILDING AND THE INSERTION ENVIRONMENT}

Vilanova Artigas building was built from the end of 1966 to early 1969, at Cidade Universitária, Universidade de São Paulo, metropolitan region of the city of São Paulo. It has $18,600 \mathrm{~m}^{2}$ of built area distributed in a set of eight floors.

The major constructive material is cast-in-place exposed reinforced concrete. The board-formed concrete blind façades, object of this study, are important elements in the composition of the building. Both the modular pattern of the boards and wood grain texture are imprinted on the outer surface of the walls and extend to the intersection of the pyramidal base of the outer pillars. In addition to other attributes, the esthetic and formal characteristics of the building resulted in its listing in 1982 and in 1991 by state and municipal preservation institutions, respectively, as quoted in Oliveira et al. [20].

Figure 1a shows the building placement (rectangular block with plan measures of $110.20 \mathrm{~m}$ x $66.20 \mathrm{~m}$ ). Figure $1 \mathrm{~b}$ shows the partial view of the main façade of the building. The façades are identified according to their orientation. The main SW façade and the NE façade have length of $110.20 \mathrm{~m}$; NW and SE façades, $66.20 \mathrm{~m}$. Walls' height is $8.15 \mathrm{~m}$, except for NE wall, which height is $7.25 \mathrm{~m}$. Thickness of walls is $200 \mathrm{~mm}$. The analysis of available original blueprints indicates cracking control reinforcement with $8 \mathrm{~mm}$ diameter, arranged in orthogonal mesh with inter-bar spacing of $100 \mathrm{~mm}$ or $200 \mathrm{~mm}$, and $10 \mathrm{~mm}$ concrete cover according to the structural design [21].

\subsection{Brief history of interventions}

The building turned 50 years of service in 2019. There are no records about any preventive maintenance performed on its façades within the 4 decades that succeed its inauguration (1969-2012). There are punctual records of replacement of the walls-bearing pad system: in 1981 (Pillar P3, NE façade) and 2000 (Column P48, SW façade -). In 2009-2010, flashings were installed on the top of wall to prevent rain water penetration. Signs of deterioration of the exposed concrete, stemming from reinforcement corrosion, were reported in 1999, during inspection that preceded the replacement of the wall-bearing pad system on pillar P48. The inspection report was the first document containing recommendation for structural patch repairs on the façades. In 2004, Simões [22] performed visual inspection in the building and identified several regions of the façades with disaggregation, pathological manifestation characterized by detachment of the concrete cover, indicating worsening deterioration of the reinforcement. In November 2012, an extensive intervention campaign started to repair the outer surface of the façades, together with other repair services in the roof and interior of the building. The campaign was completed in April 2015. Figure 1b shows the patch repairs of the main façade, performed in 2013-2014.

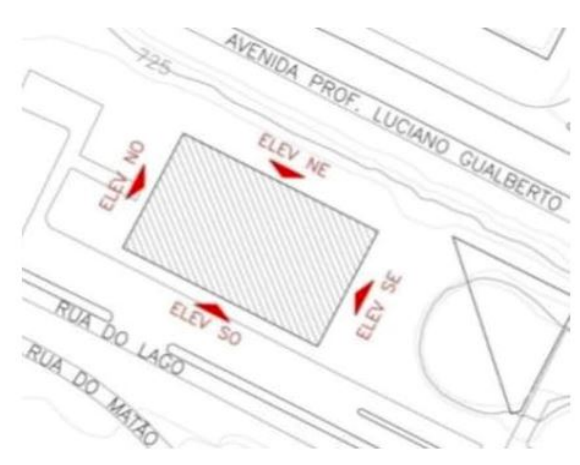

(a)

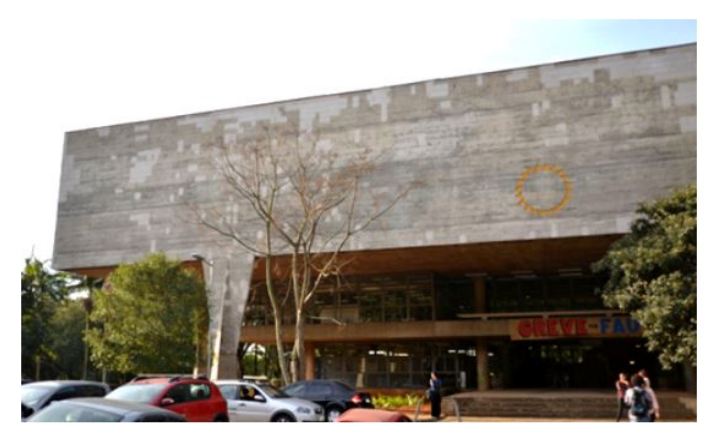

(b)

Figure 1. (a) Building placement with direction of Northeast (NE), Southeast (SE), Southwest (SO) and Northwest (NO) façades; (b) and partial view of the main façade (SW). (Photo: Authors' collection, 2016). 
In restoration of the exposed concrete built heritage, regardless on the listed or not listed status, the patch repairs should be designed to visually match the original material and to have compatible physical and mechanical properties to the parent concrete.; the purpose is to minimize visual fragmentation of the surfaces, maintaining the building uniformity. Aesthetics issues arising from the interventions carried out in 2012-2015, which cover the façade restoration, can be found in other publications [23], [24].

The technical specification for execution of the patch repairs was based on the standard engineering procedure for rehabilitation of reinforced concrete structures, by using industrialized cement-based mortar, modified with polymers and reinforced with fibers, followed by application of solvent based silane-siloxane water repellent, and a finish coat of pure acrylic varnish (without styrene) dispersed in solvent. The lack of in-depth studies on the visual impact of varnish led the board of the institution to decide for not applying this finish coat; other technical reasons also supported that decision, such as lack of studies on the full-scale application method and on the efficiency of the system in protecting such a porous and irregular surface, which should not be plaster-finished, in addition to implications, still unknown, on the maintenance of this protection without affecting the original concrete characteristics.

Figure 2 shows the aspect of the exposed concrete surface of the façades at the onset of the 2012-2015 intervention campaign (Figure 2a) and the disaggregated concrete areas with exposure of the corroded reinforcement (skin rebar), and with small covering thickness (Figure 2b).

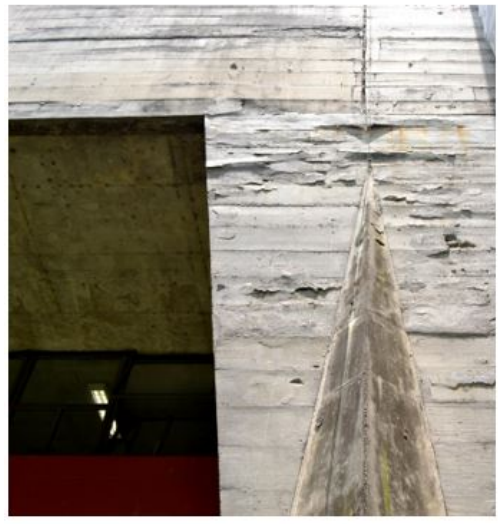

(a)

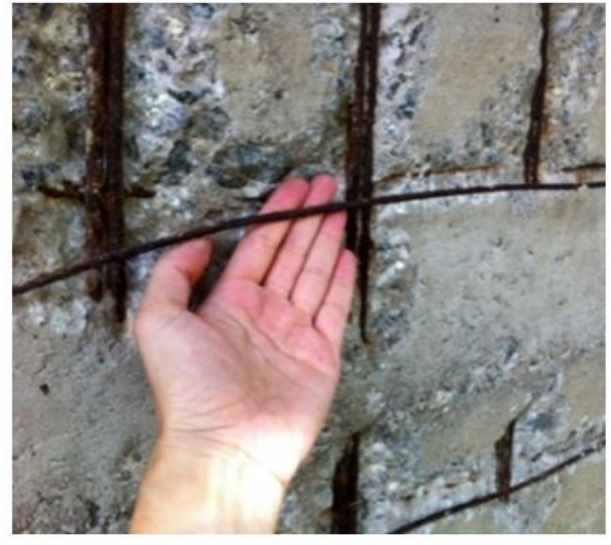

(b)

Figure 2. Partial view of NE façade: (a) area with concrete disaggregation on pillar P3 and (b) exposure of corroded reinforcement steel (Photos: authors' collection, 2013).

The photographic records taken during the intervention suggest that the skin rebar of the façades is more prone to corrosion, presenting concrete cover with variable thicknesses.

\subsection{Environmental condition}

According to previous study on the atmospheric corrosivity [25], the building surroundings can be classified as urban environment, with moderate concentration of pollutants. This environment is defined by ABNT NBR 6118:2014 [26] standard as Class II, moderate aggressiveness for reinforced concrete structures.

Monitoring of the atmospheric air between 2006 and 2017, presented in Companhia Ambiental do Estado de São Paulo [27], registered gradual decrease of atmospheric pollutant concentration in the State of São Paulo. The exception was carbon dioxide $\left(\mathrm{CO}_{2}\right)$, decreasing in the last years after strong trend of gradual increase. In regard to sulfur dioxide $\left(\mathrm{SO}_{2}\right)$, typical gas of industrial and vehicle emission environments, the decrease was very significant, and within the metropolitan region of São Paulo, the atmospheric concentration of $\mathrm{SO}_{2}$ was reduced from $16 \mu \mathrm{g} / \mathrm{m}^{3}$ in 2000 to $3 \mu \mathrm{g} / \mathrm{m}^{3}$ in 2017 [27].

Climate in São Paulo, with tropical characteristics, favors the development of corrosion process on concrete structures, as it provides conditions for frequent humidification of the concrete (reducing the concrete resistance to the current corrosion flow) and access of oxygen in the concrete/steel interface (oxidizing agent of the corrosion reactions) [25]. The trend for increase of the humidification condition can be verified by the total rainfall in 2017, amounting to $1648.8 \mathrm{~mm}$ in 
187 rainy days, $16.7 \%$ above the average value from time series. The highest temperature registered in 2017 was $36.1^{\circ} \mathrm{C}$ (October) and the lowest one $5.6^{\circ} \mathrm{C}$ (June). Although the annual relative humidity (RH) mean in 2017 has been $79.5 \%$, slightly above the average value from time series $(81.2 \%)$ [28], the trend for higher frequency and rain intensity within the last decades have been confirmed by studies of time series for the metropolitan region of São Paulo (RMSP) [29].

The driving-rain index (DRI), presented in Simões [21], was estimated based on 2016 data, for January and February (summer), and July and August (winter), which are representative of the highest and lowest annual rainfall, respectively. In the DRI graphical representation for each cardinal direction, the SE façade is the most affected by driving-rain in summer; and SE and NW façades are the most affected in winter.

\section{METHOD}

Preliminary inspection was carried out along the whole extension of the façades, combined with review of documents containing results of characterization tests of the repair areas and the original concrete. Next, a detailed inspection was conducted in the sampling areas delimited on each one of the four façades, including physical, chemical and electrochemical tests. From the interpretation of the data and results of these inspections and tests, combined with review of the precedent interventions and local environment conditions, we concluded on the conservation conditions of the reinforcements, and provided considerations on new interventions in this heritage asset to extend its residual service life and preserve its the ascribed heritage values.

\subsection{Preliminary inspection and document review}

Upon the general inspection, we have the aim of identifying the key singularities of the concrete surface, such as porosity and natural irregularity, as well as void areas, resulting from the constructive process of the structure. This phase also determined sampling areas for detailed inspection.

As it is a listed building, the detailed inspection, which would require the conduction of destructive tests, was preceded by preparation of detail project approved by advisory councils for historic preservation. Scarifications were authorized on the façades, for potential and corrosion rate measurements, in the repaired areas only. By considering these restrictions, we selected areas for detailed inspection, one for each façade. The selection was made based on the following criteria: accessibility in function of the building dimensions and proximity of the trees; areas with lower surface heterogeneity and that permitted fitting of two or three patch repairs, areas close to the selected locations for extracting concrete cores.

It must be emphasized that the preservation councils also limited the number of cores to four (diameter $50 \mathrm{~mm}$ and length $200 \mathrm{~mm}$ ). Therefore, two samples were extracted from the NE façade and two from the NW façade, as they were the façades with largest and smallest repaired areas, respectively.

Data from other surveys and tests presented in Simões [21] were reviewed to support result interpretation and analysis:

- Area and positioning of the structural patch repairs, determined by laser scanning, complemented with photos and onsite inspections; the scanning methodology adopted can be found in Balzani et al. [30];

- Corrosion products deposits (corrosion spots) identified by direct visual observation and use of binoculars;

- Dampened areas detected after moderate rainfall during the day; moisture stains were identified by photographic records taken in early evening, once finished the rain.

- Concrete cover measured with metal detector (Bosch D-TECT 150) in 393 positions distributed on four façades;

- Concrete compressive strength of cores samples extracted from NE and NW façades, according to ABNT NBR 7680-1: 2015 [31];

- Mixture proportion reconstitution of the original concrete based on methods presented in Quarcioni [32] and Instituto de Pesquisas Tecnológicas [33].

\subsection{Detailed inspection}

Detailed inspection of the concrete surface was conducted in the areas selected in each façade, by using articulated lifting platform, in January-February 2017, at time when building turned 49 year old.

Each area was delimited with reference grid drawn on the concrete surface, with white chalk, $15 \mathrm{~cm} \times 15 \mathrm{~cm}$ intervals, following the existing board-marking on the surface (planks with height $30 \mathrm{~cm}$ ). The grid makes easier the registration of pathological manifestations and is suitable for mapping the gradient of corrosion potential values. Each 
value range is represented by one color or contour line. Regions with significant variation of colors or concentration of contour lines are potentially considered as more prone to corrosion.

The visual observation was performed to identify the key surface characteristics of concrete: segregated concrete/segregation, disaggregated concrete/disaggregation, exposed reinforcement, local corrosion spot/stain, surface air voids, cracking and hollow sound, according to the method described in Araujo and Panossian [34].

By using common scale, vernier caliper and crack gauge, the dimensions of surface air voids and the crack openings were determined.

Regions with hollow sound were located by using geologist's percussion hammer. The location of these regions is of interest of research, as it indicates voids in poorly compacted areas or inner cracking of the repair concrete or mortar.

Visual examination of the reinforcement was made after fracture in the repaired areas. The surface of the section newly exposed of the rebars (near-surface reinforcement) and the original concrete beneath it, and the original concrete/repair mortar interface were examined by naked eye. The major purpose of this examination was to evaluate the passive or active corrosion condition, with the active condition being usually characterized by the presence of corrosion products on the reinforcement/cementitious material interface [34].

The diameter of exposed rebars was measured with vernier caliper after mechanical cleaning for removal of the major part of corrosion products. The carbonation depth was measured by using a solution of phenolphthalein indicator, according to DIN EN 14630 [35].

To minimize the interference of the water repellent impregnant on the corrosion potential measurements, the concrete surface was strongly sanded, followed by moistening by period longer than that usually required for nonimpregnated concrete. The corrosion rate measurements required an additional phase: brushing with nylon bristle brush, water and mild soap, followed by water spray during 45 minutes.

The corrosion potential (Ecorr) of the reinforcement was determined by a series of measures, on the reference grid, providing a gradient map with $50 \mathrm{mV}$ intervals. The corrosion rate (icorr) was determined in some sections of the reinforcement, previously delimited within the reference grid limits. The electrochemical measurements were carried out with CorrMap equipment using $\mathrm{Ag} / \mathrm{AgCl}$ reference electrode - EPCP (209 mV vs. standard hydrogen electrode), adopting a procedure similar to that used in Araujo et al. [36].

To determine the surface moisture content (up to $30 \mathrm{~mm}$ depth), we used Moist 210B equipment, based on the microwave emission and reception, frequency range from $300 \mathrm{MHz}$ to $300 \mathrm{GHz}$.

\section{RESULTS}

\subsection{Preliminary inspection and document review}

Several concrete segregation regions were identified on the construction joints and along the line between planks that composed the mold of the outer face of façades. In addition to the relief already mentioned produced by the wood grain imprinted on the concrete surface, other characteristics of the façade surfaces must be highlighted, such as air voids on the surface, resulting from entrapment air, bubbles as shown in Figure 3.

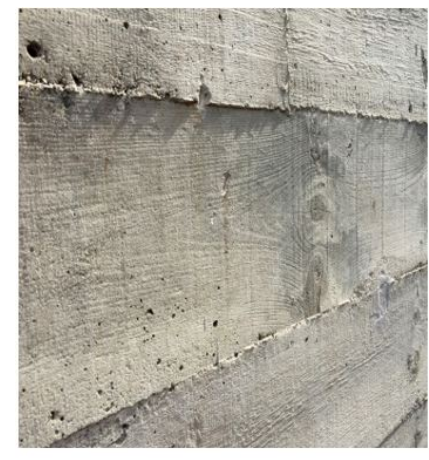

(a)

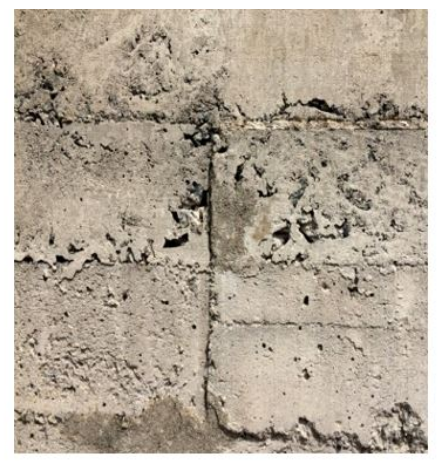

(b)

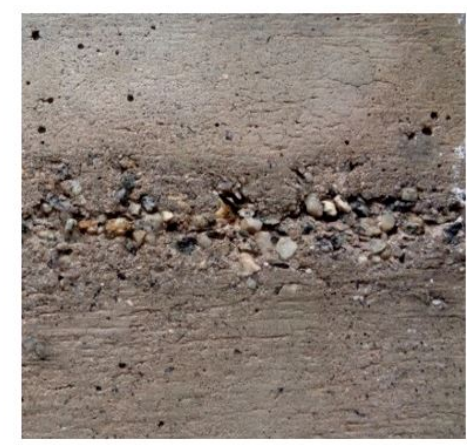

(c)

Figure 3. Characteristics of the exposed concrete of façades in Artigas building: (a) wood grain pattern on the surface (width $30 \mathrm{~cm}$ ); (b) rough surface texture and air voids; (c) segregation in construction joint. (Images: Collection of ConservaFAU, 2016). 
These characteristics favor the deposition of particulate material, penetration of water and aggressive agents, which can be evidenced by dirt stains (carry of particulate material by storm water) and stains of steel corrosion products present throughout the façade extension.

The number of patch repairs and corrosion spots is shown in Table 1. Repairs are randomly dispersed on the façade surfaces, in several shapes and dimensions. Although the visual heterogeneity of concrete is a building characteristic since its inauguration, the repaired areas add variations to the façade surfaces in terms of texture, chromaticity and brightness, different from the parent concrete, which gains proper nuances with aging (Figure 1 and Figure 4).

NE façade had the greatest percentage of patch repairs, followed by SE façade. A total area of $727 \mathrm{~m}^{2}$ was repaired, which is equivalent to replacement of approximately $24 \%$ of the original concrete.

Table 1. Number and total area of patch repairs and respective fraction of area repaired in each façade; number of corrosion spots. Inspections made in 2016.

\begin{tabular}{cccccc}
\hline Description & \multicolumn{3}{c}{ Façades } & \multicolumn{2}{c}{ Total } \\
\cline { 2 - 5 } & SW & SE & NE & NW & 589 \\
\hline Façade area $\left(\mathrm{m}^{2}\right)$ & 993 & 588 & 901 & 3071 \\
\hline Total number of repairs & 295 & 146 & 305 & 194 & 940 \\
\hline Fraction of repaired area $(\%)$ & 16 & $\mathbf{2 4}$ & $\mathbf{3 7}$ & 16 & $\mathbf{2 4}$ \\
\hline Repair area $\left(\mathrm{m}^{2}\right)$ & 159 & $\mathbf{1 4 1}$ & $\mathbf{3 3 3}$ & 94 & $\mathbf{7 2 7}$ \\
\hline Total number of corrosion spots & 153 & 58 & 71 & 131 & 413 \\
\hline Fraction of corrosion spots $(\%)$ & 15 & 10 & 8 & 22 & --- \\
\hline
\end{tabular}

Moisture stains are present on all the façades with the most significant dimensions on the NE façade, although more dispersed on the SW façade. Figure 4 shows typical moisture stains, suggesting water repellent impregnation failure. The surface moistening also makes cracks in the patch repairs noticeable.

The cover depth, measured in 393 positions by metal detector, results in the distribution shown in Figure 5 . Note the predominance cover within the range up to $10 \mathrm{~mm}$.

For cores extracted from the two façades, the average compression strength was $38 \mathrm{MPa}$, above $32 \mathrm{MPa}$, which is indicated as characteristic concrete compressive strength in original structural design. Observation of the samples reveals a well compacted concrete, but with outer end (outer surface of the façade) more porous. For core extracted from NW façade, the carbonation depth ranged from 1 to $2 \mathrm{~mm}$ on the outer surface, and 14 to $18 \mathrm{~mm}$ on the inner face. For core extracted from NE façade, the carbonation depth ranged from 20 to $25 \mathrm{~mm}$ on the outer face, and $30 \mathrm{~mm}$ on the inner face. Concrete strength is greater than the values achieved for concretes in buildings with similar characteristics, in urban environments, 50 year service life (24 MPa [16]; $22 \mathrm{MPa}$ [17]; 11.3 to 24.1 $\mathrm{MPa}$ [18]); the carbonation depths measured are equivalent or less than the maximum values measured by other researchers (76 to $102 \mathrm{~mm}$ [16]; $31 \mathrm{~mm}$ [17]; $43.5 \mathrm{~mm} \mathrm{[18];} 5$ to $95 \mathrm{~mm} \mathrm{[19]).}$

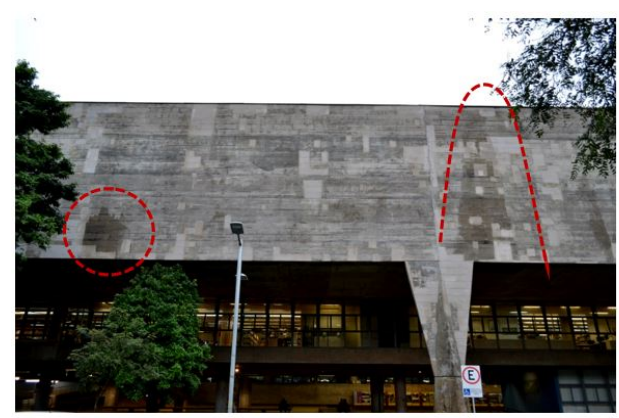

(a)

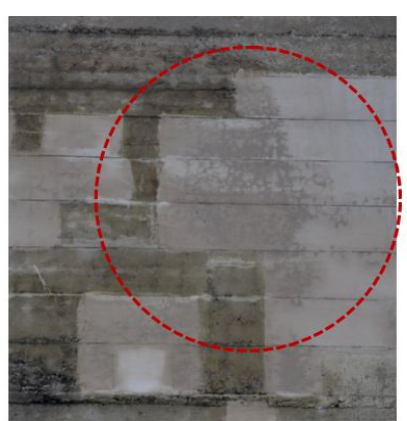

(b)

Figure 4. Partial views of SW façade: (a) typical moisture stains and (b) noticeable patch repair cracking after rain water penetration (Photos: Authors' collection, 2017).

According to the mixture proportion reconstitution the average consumption of cement and the cement: aggregates ratio were estimated as $409 \mathrm{~kg} / \mathrm{m} 3$ and 1:4.1 for NE façade, and $424 \mathrm{~kg} / \mathrm{m} 3$ and 1:3.9 for NW façade. The reconstitution 
method assumes water/cement ratio of 0.50 , consistent which the values adopted at the building construction time, as indicated in the specialized literature of the engineer Abílio Azevedo Caldas Branco apud Thomaz [37].

According to the Brazilian standard for design of reinforced concrete structures, ABNT NBR 6118: 2014 [26], the building is located in a class II (moderate) aggressiveness environment, condition that requires the use of concrete with compressive strength equal or greater than $25 \mathrm{MPa}$, w/c ratio equal or less than 0.6 , and nominal concrete cover of $30 \mathrm{~mm}$. The results suggest that the façade concrete provides properties compatible with the guidelines for durability of concrete structures in line with referred standard. Exception is made for the concrete cover, which, according to the measurements taken (Figure 5 and Table 2), has large variation, with predominance of values less than the ones defined in ABNT NBR 6118 [26].

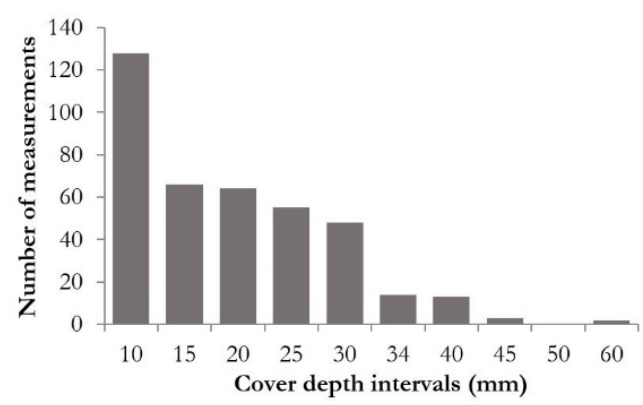

Figure 5. Distribution of cover depth measured on the façades of the Artigas building.

\subsection{Detailed inspection}

Figure 6 shows the general aspect of two areas inspected with location of patch repairs and numerical grid. Although not clearly visible in the figure, some of the concrete characteristics mentioned are indicated with white chalk, with predominance of concrete segregation regions (S) and surface air voids (AV). Black arrow in Figure $6 \mathrm{~b}$ indicates the place where two cores were extracted in NW façade. Cracks (C) with variable opening (most $\leq 2 \mathrm{~mm}$ ) were observed on the repair mortar; these fissures affect adversely the performance of concrete by favoring the water ingress.

Regions with hollow sound were located in all the areas inspected (in repair mortar an in concrete). Finally, some sections of the exposed reinforcement were related to stains of corrosion products (corrosion spots) observed in the preliminary inspection. Some of these spots correspond to devices (steel pin or bar) probably used for fastening wall form elements. Measurements made directly on the exposed reinforcement suggest nominal rebar diameter of $8 \mathrm{~mm}$, as indicated in the review of the original design.

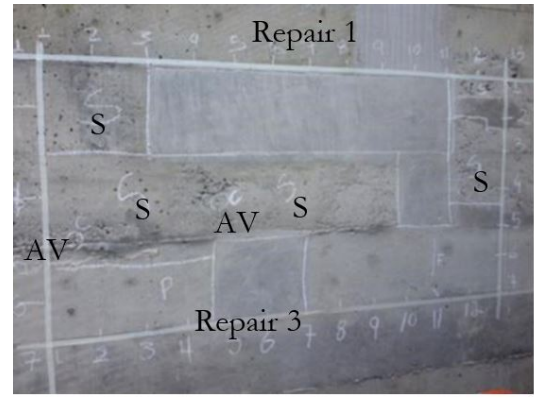

(a)

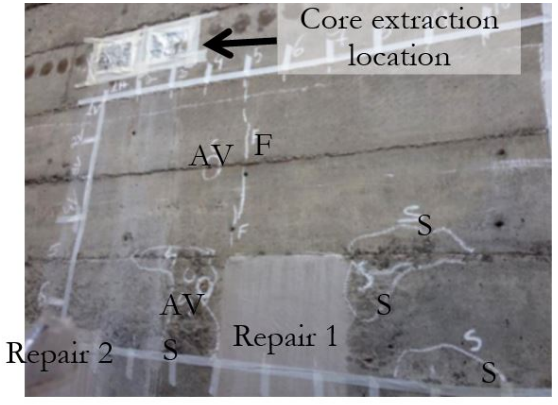

(b)

Figure 6. General aspect of the area inspected with identification of repairs: (a) on SW façade and (b) on NW façade (Photos: Authors' collection, 2017).

Table 2 shows the results achieved in the evaluation of repairs, and of the concrete around these repairs, in the areas inspected. The cover, after fracture of the repair, ranged from 8 to $33 \mathrm{~mm}$, which are values compatible with the intervals of the previous survey (Figure 5). The visual examination of sections newly exposed of the reinforcement indicated active corrosion state, checked by the presence of stains with typical colors of corrosion or accumulation of its products. In 
most of the repairs inspected, the reinforcement is not totally surrounded by the repair mortar, but by carbonated concrete. The only reinforcement section wrapped by repair mortar was the exposed one in Repair 2 of SE façade, however the repair mortar presented a well-defined map cracking, a typical failure mode that favors water penetration. Figure 7 shows sections of exposed reinforcement in the repairs inspected. In Figure $7 \mathrm{~b}$, we can observe the carbonation depth in the repair mortar, and in the underlying concrete as well. The average carbonation depth in mortar was very variable (4 to $29 \mathrm{~mm}$ ), and some values are close or greater than the concrete cover, indicating that the corrosion was caused by $\mathrm{pH}$ reduction.

Table 2. Results of inspection of the reinforcement newly exposed in the repair area of the façades; measurements of the cover and carbonation depth.

\begin{tabular}{|c|c|c|c|c|c|c|c|c|c|c|c|}
\hline & \multirow{2}{*}{\multicolumn{2}{|c|}{ Description }} & \multicolumn{3}{|c|}{ Southwest } & \multicolumn{2}{|c|}{ Northwest } & \multicolumn{2}{|c|}{ Northeast } & \multicolumn{2}{|c|}{ Southeast } \\
\hline & & & Repair 1 & Repair 2 & Repair 3 & Repair 1 & Repair 2 & Repair 1 & Repair 2 & Repair 1 & Repair 2 \\
\hline \multirow{6}{*}{ 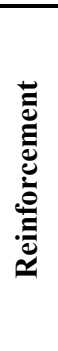 } & \multirow{4}{*}{ ¿े } & \multirow{3}{*}{ 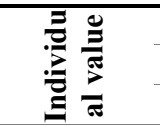 } & 29 & 30 & 33 & 14 & 15 & 11 & 12 & 7 & 20 \\
\hline & & & 29 & 30 & 33 & 15 & 15 & 8 & 12 & 8 & 20 \\
\hline & & & 29 & 30 & 33 & 17 & 15 & 10 & 12 & 8 & 20 \\
\hline & & Average & 29 & 30 & 33 & 15 & 15 & 10 & 12 & 8 & 20 \\
\hline & \multicolumn{2}{|c|}{ Surface color } & $\begin{array}{l}\text { Brown/ } \\
\text { orange }\end{array}$ & $\begin{array}{l}\text { Black/ } \\
\text { orange }\end{array}$ & $\begin{array}{l}\text { Brown/ } \\
\text { black / } \\
\text { orange }\end{array}$ & $\begin{array}{l}\text { Gray / } \\
\text { orange }\end{array}$ & $\begin{array}{l}\text { Brown/ } \\
\text { orange }\end{array}$ & $\begin{array}{l}\text { Gray / } \\
\text { orange }\end{array}$ & $\begin{array}{l}\text { Brown/ } \\
\text { orange }\end{array}$ & $\begin{array}{l}\text { Gray / } \\
\text { orange }\end{array}$ & $\begin{array}{l}\text { Gray / } \\
\text { orange }\end{array}$ \\
\hline & \multicolumn{2}{|c|}{$\begin{array}{c}\text { Electrochemical state } \\
\text { assigned }\end{array}$} & Active & Active & Active & Active & Active & Active & Active & Active & Active \\
\hline \multirow{11}{*}{ 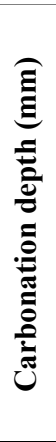 } & \multirow{6}{*}{ 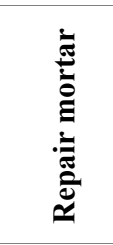 } & \multirow{5}{*}{ 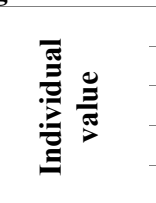 } & 16 & 3 & 30 & 4 & 5 & 3 & 15 & 5 & 9 \\
\hline & & & 8 & 3 & 34 & 7 & 5 & 15 & 15 & 7 & 10 \\
\hline & & & 7 & 3 & 24 & 5 & 3 & 10 & 12 & 5 & 8 \\
\hline & & & 4 & - & 27 & 4 & 8 & 7 & 11 & 8 & 8 \\
\hline & & & 11 & - & 28 & - & 6 & - & - & 10 & 7 \\
\hline & & Average & 9 & 3 & 29 & 5 & 5 & 9 & 13 & 7 & 8 \\
\hline & \multirow{5}{*}{ U் } & 可 & 17 & 34 & 33 & 16 & \multirow{4}{*}{$17(* *)$} & \multirow{4}{*}{$22(* *)$} & \multirow{4}{*}{$22(* *)$} & \multirow{4}{*}{$15(* *)$} & \multirow{4}{*}{$\begin{array}{l}>26 \\
(* * *)\end{array}$} \\
\hline & & . & 15 & 38 & 34 & 19 & & & & & \\
\hline & & :를 & 22 & 17 & 26 & 11 & & & & & \\
\hline & & $\Xi>$ & 14 & 32 & 25 & 25 & & & & & \\
\hline & & Average & 17 & 30 & 30 & 18 & 17 & 22 & 22 & 15 & - \\
\hline
\end{tabular}

$(*)$ Depth of concrete analyzed beneath the mortar; $(* *)$ Single measurement; $(* * *)$ Carbonation front not detected to scarification of $26 \mathrm{~mm}$

Upon repair evaluation, the measurements suggest the carbonation depth reaches approx. $20 \mathrm{~mm}$, which affects durability of exposed concrete façade given the corrosion-related pathological manifestations. The carbonation progression in the mortar within 4 years - may has been influenced by lack of varnish coat, not applied by the reasons indicated in 2.1. The reinforcement sections with cover less than $20 \mathrm{~mm}$ shall be depassivated and in an active corrosion process.

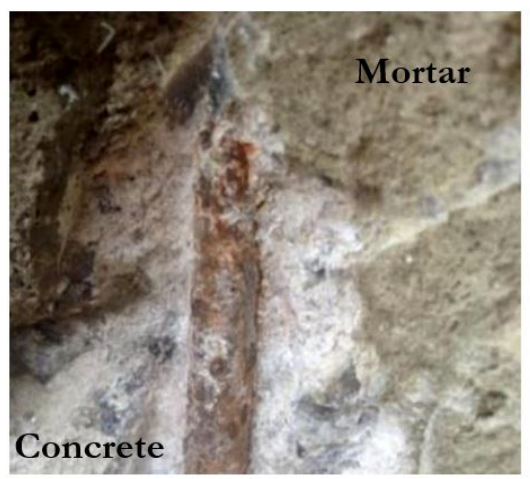

(a)

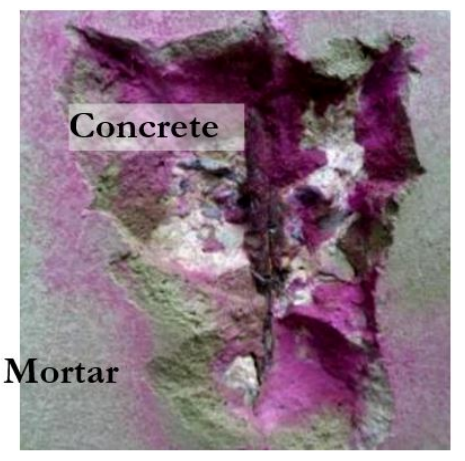

(b)

Figure 7. Exposed reinforcement during inspection: (a) on Repair 3 of SW façade and (b) on Repair 2 of NW façade (Photos: Authors' collection, 2017). 
Figure 8 shows that the gradient of surface moisture, down to $30 \mathrm{~mm}$ depth, was not significant, prevailing the range 4 to $6 \%$ on SW façade (Figure $8 \mathrm{a}$ ) and 6 to $7 \%$ on NW façade (Figure 8b). In addition, no change was observed in the moisture content in localized repair regions, and neither any correlation of the moisture content maps vs. corrosion potential maps (see Figures 8c and 8d) in the same inspection area.

Each corrosion potential range is represented by a color in Figures $8 \mathrm{~b}$ and $8 \mathrm{c}$. The concentration of contour lines, with potential variation equal or greater than $150 \mathrm{mV}$, indicates regions more prone to corrosion [38]. The location and frequency of these regions in the structural elements are the bases for decision-making on interventions. For both maps of Figures $8 \mathrm{c}$ and $8 \mathrm{~d}$, we observe regions with significant potential variation.

The positive values of potential for carbonated concrete of Figure $8 \mathrm{c}$ and $8 \mathrm{~d}$ corroborate the results of Elsener et al. [39] and Araujo et al. [36], and enforce the importance of potential mapping in the assessment corrosion risk of the reinforcement under these conditions. Data in Figures $8 \mathrm{c}$ and $8 \mathrm{~d}$ indicates significant variation of values in the repair region, which present higher risk of corrosion, i.e. electrochemical cells locations This activity was checked by examining the reinforcement beneath the repair, which evidenced accumulation of corrosion products on its surfaceMost of the values achieved for the corrosion rate were greater than $1.0 \mu \mathrm{A} / \mathrm{cm}^{2}$ (section loss $\geq 10 \mu \mathrm{m} /$ year), indicating severe corrosion [40]. However, it must be considered that values above $1.0 \mu \mathrm{A} / \mathrm{cm}^{2}$ are typical of concrete exposed to relative humidity $(\mathrm{RH})$ above $90 \%$, which is a condition not verified locally, where the average value from time serie is $81.2 \%$. Considering the local RH between $70 \%$ and $90 \%$, the reinforcement corrosion rate must vary, and may increase significantly only under conditions of high relative humidity content, or in periods of intense and frequent rainfall.
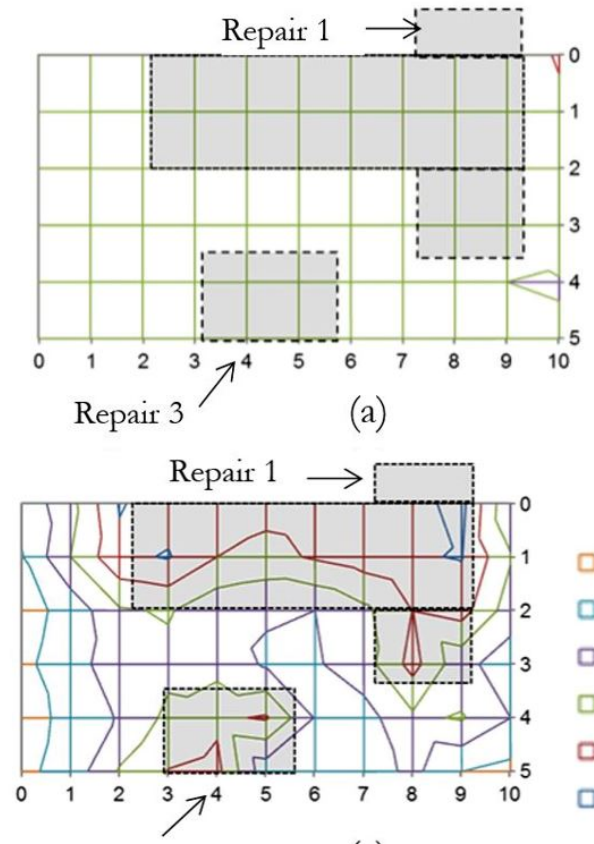

Repair 3 $\square 6-8$

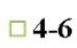

$\square 2-4$

$\square$ 0-2

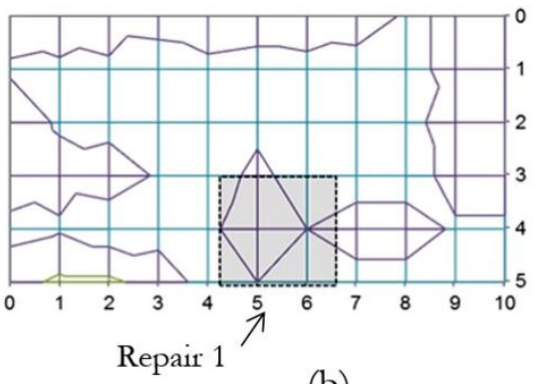

(b)

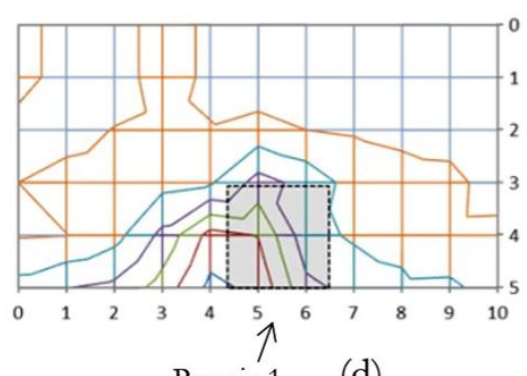

Repair 1 $\square$ 6-7

$\square 5-6$

$\square$ 4-5

$\square$ 3-4

$\square$ 2-3

$\square-50$ to 0

$\square-100$ to -50

$\square-150$ to -100

$\square-200$ to -150

$\square-250$ to -150

$\square-300$ to -250

$\square-350$ to -300

Figure 8. Surface moisture content map (\%) in inspected area: (a) on SW façade and (b) on NW façade. Corrosion potential map (EPCP electrode) in inspected area: (c) on SW façade and (d) on NW façade. Corrosion potential values (mV).

\section{RESULT ANALYSIS}

The limit imposed by advisory councils for historic preservation for extraction of materials and destructive tests is a challenge faced during investigations, and also reported by other researchers [41]. In the present study, these restrictions limited the investigation to few localized areas, and the fracture in repaired areas only, which are inappropriate conditions for evaluation of large-size structure and extensive surface exposed to weathering.

In this scenario, the result analysis is based on uncertainties, which however could be overcome due to the methodological approach adopted. The differential of the methodology used in this research was the combination of 
several techniques, which were evidenced as effective for assessment of the reinforcement current conditions. The past interventions, local conditions, environmental aggressiveness and preliminary inspection composed the reference basis for result analysis, and were essential for deepening the understanding of the structure performance. Among the techniques, we highlight the corrosion potential mapping, which combined to the reinforcement observation, evidenced the active corrosion conditions of the rebars in the areas inspected. The investigations also proved the need for uniform wetting to reduce interference on the corrosion potential measurements, caused by the residual water repellent impregnation and the high electric resistivity of carbonated concrete.

Visual examinations of the newly fractured reinforcement, combined to the thickness of its cover and the carbonation depth, suggest that the corrosion in progress was due to carbonation of the concrete cover, which presented very variable thickness, in addition to cracks, air voids and surface irregularities. The inefficacy of the water repellency effect also contributes for the scenario. Although this inefficacy can be partially assigned to flaws in the application process of the water repellant, upon the present study the product re-application term was already expired, according to the maintenance manual provided by the company in charge of the intervention. Additionally, the lack of efficacy of the water repellent is also related to segregation, cracks, air voids of the concrete surface, which exceed the maximum opening limits $(0.3 \mathrm{~mm})$, not requiring filling before application of the product [42].

Onsite measurements suggest that the carbonation depth is equal or greater than the concrete cover in virtually the whole extension of façades, and considering the corrosion history of the building, the current condition fits within the propagation period, according to Tuuti [43] model. Within this period, the extension of the residual service life depends on the corrosion rate and its consequences over time. Thus, the reduction of the corrosion rate is the major focus of the strategy for façade conservation.

In Alonso and Andrade apud Bertolini [44] the definition is clear: in the corrosion by carbonation, once the carbonation front has reached the reinforcement and the steel is depassivated, the corrosion rate is controlled by water and oxygen availability on the reinforcement surface. Oxygen availability is very low only in the condition where the concrete is fully and permanently saturated with water [44]. Under other exposure conditions, the corrosion rate of steel in carbonated concrete is ruled by the electric resistivity of concrete. Therefore, for the structure in question, exposed to intermittent period of wetting, the moisture content of concrete is the prevailing parameter of the electric resistivity of the material, and consequently of the corrosion rate of the reinforcement.

By considering that the active corrosion state of the reinforcement, the environmental condition and the characteristics of the outer face of the façades investigated, the conservation plan shall consider a systemic approach focused on the 3 principles of BSI EN 1504-9 [45] (1) preservation or restoration of passivity; (2) control of the anodic area, and (3) protection against penetration / control of humidity.

The first principle is related to the identification of patch repairs that should be redone due to onsite conditions (carbonation front and map cracking, and active corrosion of reinforcement), as well as the new repairs, especially in zones with corrosion deposits and hollow sound. The system that combines industrialized mortar (thixotropic, Portland cement-based, modified with polymer and corrosion inhibiting admixture) and anti-corrosion primer applied on the exposed reinforcement is the proper option. But in this specific case, it would be beneficial a new approach for the mix design of repair mortars together in association with the manufacturers interested in supplying a product custom-made aiming to meet the aesthetic requirements.

The second principle guides the general treatment of the façade surfaces with impregnation of outer surfaces with migration corrosion inhibitor, compatible with the one adopted in the repair system. Impregnation shall be made after removal of the residual water repellent. The application of the corrosion inhibiting agent has the purpose of restricting the natural electrochemical incompatibility between the repair mortar and the original carbonated concrete. Although the use of migration corrosion inhibitor has been reported by Gaudette et al. [46] and MacDonald [47], due to the slight visual impact on the exposed concrete of the architectural heritage, published performance assessments of this protection over time are scarce. As the migration corrosion inhibitor efficiency depends on the final concentration of the product surround the reinforcement, previous studies are required on the migration corrosion inhibitor application method, as well as on the product penetration depth in aged carbonated concrete.

To meet the third principle, we shall proceed with surface protection of the concrete with high-performance water repellent impregnant, silane-based, with high concentration of solids, as reported in Edelson [16], aiming to prevent corrosion or to reduce the corrosion rate by controlling the concrete moisture content. This system has been used in the protection of exposed concrete architectural heritage, as reported in Slaton et al. [48]. As already highlighted in this text, the application method of water repellent and the number of layers shall be supported by previous studies before the concrete surface characteristics. In addition, impregnation does not provide protection against penetration of gases $\left(\mathrm{CO}_{2}\right.$ and water vapor), and also may contribute for progress of the carbonation front. To minimize the penetration of 
these gases and extend the protection effect of the corrosion inhibitor impregnant, and also the water repellency effect, we have the option for superficial application of alkaline silicate-based solution, which also provides greater resistance to water penetration to the surface [16].

\section{CONCLUSIONS}

The present article presented the results from inspections for assessment of the current conditions of reinforcement in the exposed concrete façades of Vilanova Artigas building. Since it is an architectural heritage, destructive tests were restricted to predefined areas, approved by the advisory councils for historic preservation. The visual inspection of the concrete surfaces evidenced the typical characteristics of exposed concrete structures produced in the Modern Movement, reported in the literature. Many of these characteristics, such as surface air voids, segregation in the construction joints and small and variable concrete cover of the reinforcement, are related to the constructive method. The corrosion deposits identified on the original concrete surfaces are evidences that the concrete cover associated to concrete surface roughness and irregularities, and also to the lack of surface protection system, were determinant for the progress of the corrosion process. In the fractured repaired areas we observed that the carbonation depth was significant in this mortar. The corrosion potential map presented significant variation of values, indicating the active corrosion state of the reinforcement. Under the surface intensely moistened condition, the corrosion rate of the reinforcement was high. As evidenced in this article, detailed study of samples of the Modern Architecture also contributes for documentation of technical aspects, related to the design and materials used in the exposed reinforced concrete production, which impacted the performance of the structure over its service life.

The chronological milestone of 50-year service life, completed in 2019, without significant damage to the structural safety and functionality, provides evidence that the performance of the concrete/reinforcement system of the building façades under study is acceptable, considering the intervention campaign of 2012-2015. However, the rough surface and segregation of the concrete, the low concrete cover to depassivated reinforcement, and the verified active corrosion state of the reinforcement, point out the need for monitoring the façades and the urgency of implementing a preventive maintenance plan, along with a conservation project in order to preserve the heritage values of the building.

\section{ACKNOWLEDGEMENTS}

Authors thank The Getty Foundation, IPT and IFSP for the support provided to the research.

\section{REFERENCES}

[1] C. S. R. Carvalho, "Preservação da arquitetura moderna: edifícios de escritórios construídos no Rio de Janeiro entre 1930 e 1960 ," Ph.D. dissertation, Fac. Arquit. Urban., Univ. São Paulo, São Paulo, 2005.

[2] M. O. Guimarães, "Cinquenta tons de cinza: escalas de ação e de valorização do concreto aparente na Universidade de Brasília," in Sem. Docomomo Brasil, 2019. [Online]. Available: http://docomomo.org.br/course/13o-seminario-docomomo-brasil-salvador/

[3] F. H. Pinto and F. D. Moreira, "Intervenções em superfícies de concreto aparente e os valores da arquitetura moderna: o caso do edifício sede da CELPE - Companhia Energética de Pernambuco," Rev. CPC, no. 21, pp. 119-139, Jan./Jul. 2016, https://doi.org/10.11606/issn.1980-4466.v0i21p119-139.

[4] F. L. H. Pinto, “O concreto aparente como atributo na conservação da arquitetura moderna,” M.S. thesis, Prog. Pós-grad. Desenvolv. Urban., Cent. Artes Comun., Univ. Fed. Pernambuco, Pernambuco, 2012.

[5] M. P. Rocha, "Patrimônio arquitetônico moderno: do debate às intervenções," M.S. thesis, Prog. Pós-grad. Arquit. Urban., Univ. Fed. Paraíba, Pernambuco, 2011.

[6] C. T. A. Oliveira et al., "O restauro do moderno: o caso do edifício Vinanova Artigas da FAUUSP," in An. $7^{\circ}$ Sem. Docomomo Brasil, 2007, 12 p.

[7] C. S. S. M. Castro, "Para além das aparências: contribuição ao estudo da conservação de superfícies arquitetônicas de concreto aparente,” M.S. thesis, Fac. Arquit. Urban., Univ. São Paulo, São Paulo, 2018.

[8] D. C. V. B. C. Oliveira, "Restauração do concreto aparente: estudo tecnológico para salvaguarda de edificações com tendências modernistas,” M.S. thesis, Progr. Pós-grad. Arquit. Urban., Inst. Tecnol., Univ. Fed. Pará, Belém, 2013.

[9] International Docomomo Seminar, The Fair Face of Concrete: Conservation and Repair of Exposed Concrete. Preceedings. Eindhoven: DOCOMOMO International, Eindhoven University of Technology, 1998, p. 151. [Online]. Available:

https://issuu.com/docomomoisctechnology/docs/dossier_2_-_the_fair_face_of_concre 
[10] P. E. Gaudette and H. J. Hunderman, “Multiphased Approach - Promontory Apartments, Chicago (Mies Van der Rohe, 1949). Eindhoven: DOCOMOMO International, Eindhoven University of Technology, 1998, pp. 127-134. [Online]. Available: https://issuu.com/docomomoisctechnology/docs/dossier_2_-_the_fair_face_of_concre

[11] J. P. Oudot, A Delay of Decay - Notre Dame de Royam (Guillaume Gille, 1955). Eindhoven: DOCOMOMO International, Eindhoven University of Technology, 1998, pp. 105-111. [Online]. Available: https://issuu.com/docomomoisctechnology/docs/dossier_2__the_fair_face_of_concre

[12] R. Pörtner, Patch Repair Leaves Architectural Integrity - The Beethoven Hall of the Stuttgart Liederhalle. Eindhoven: DOCOMOMO International, Eindhoven University of Technology, 1998, pp. 121-126. [Online]. Available: https://issuu.com/docomomoisctechnology/docs/dossier_2_-_the_fair_face_of_concre

[13] K. A. Van der Zanden, Brilliant Match? Pumping Station Parksluizen, Rotterdan (1968). Eindhoven: DOCOMOMO International, Eindhoven University of Technology, 1998, pp. 95-98. [Online]. Available: https://issuu.com/docomomoisctechnology/docs/dossier_2_-_the_fair_face_of_concre

[14] S. Macdonald and A. P. A. Gonçalves, "Concrete conservation: outstanding challenges and potential ways forward," Int. J. Build. Pathol. Adaptation, vol. 38, no. 4, pp. 607-618, 2020, http://dx.doi.org/10.1108/IJBPA-12-2018-0100.

[15] P. Gu et al., "Electrochemical incompatibility of patches in reinforced concrete," Concr. Int., vol. 19, no. 8, pp. 68-72, 1997.

[16] R. Edelson, “The Pentagon lightwell walls: repair, rehabilitation and protection for the next 50 years,” Struct. Mag., pp. 34-36, Jan., 2007.

[17] L. N. Buchner and R. M. Pepi, "Restoration of the cast-in-place concrete at the New York Hall of Science," APT Bull. The J. Preserv. Technol., vol. 46, no. 2-3, pp. 54-63, 2015.

[18] E. E. Maldonado-Bandala, D. Nieves-Mendoza, J. L.Vela-Jiménez and P. Castro-Borges, “Avaliação de problemas patológicos associados à carbonatação e sulfatos em uma torre de concreto com mais de 50 anos de serviço," ALCONPAT J., vol. 8, no. 1, pp. 94107. 2017, http://dx.doi.org/10.21041/ra.v8il.284.

[19] S. L. Pagliolico, R. Doglione, and J. M. Tulliani, "Diagnosis of the surface layer damage in a 1960s reinforced concrete building," Case Stud. Constr. Mater., vol. 1, pp. 77-82, 2014, http://dx.doi.org/10.1016/j.cscm.2014.04.006.

[20] C. T. A. Oliveira et al., "O restauro do moderno: o caso do edifício Vilanova Artigas da FAUUSP," in An. $7^{\circ}$ Sem. Docomomo Brasil, 2007, 12 p. [Online]. Available: http://docomomo.org.br/course/7-seminario-docomomo-brasil-porto-alegre/

[21] J. R. L. Simões, "Patologias - origens e reflexos no desempenho técnico-construtivo de edifícios: análise das origens das patologias e seus reflexos no desempenho técnico-construtivo de edifícios universitários da CUASO-USP/SP utilizando-se de edifícios da ISO6241 e procedimentos da APU - avaliação pós-uso,” Ph.D. dissertation, Fac. Arquit. Urban., Univ. São Paulo, São Paulo, 2004.

[22] C. S. S. M. Castro, A. P. A. Gonçalves, R. A. C. Vergili, R. C. Campioto, C. T. A. Oliveira, and M. L. B. Pinheiro, "Edifício Vilanova Artigas: obra de intervenção em patrimônio moderno," in Atas Cong. Ibero-Am. Património: Suas Matér. Imatér., 2016, pp. $1-20$.

[23] A. P. A. Goncalves and C. S. Saraiva, "Intervenção em concreto aparente histórico: o caso das empenas do edifício Vilanova Artigas," in An. $5^{\circ}$ Sem. Docomomo SP, 2017, pp. 166-181.

[24] M. L. B. Pinheiro et al., Subsidies for a Conservation Management Plan: Vilanova Artigas Building. São Paulo: Sch. Architec. Urban., Univ. São Paulo, 2017. Technical Report. Keeping It Modern, The Getty Foundation. [Online]. Available: $\mathrm{https}$ ://www.getty.edu/foundation/initiatives/current/keeping_it_modern/report_library/vilanova_artigas.html?q=\%7B\%7D

[25] N. L. Almeida and P. Panossian, Corrosão Atmosférica 17 Anos. São Paulo: Secretaria da Ciência e Desenvolvimento Econômico do Estado de São Paulo, 1999, p. 130.

[26] Associação Brasileira de Normas Técnicas, Projeto de Estruturas de Concreto - Procedimento, ABNT NBR 6118, 2014.

[27] Companhia Ambiental do Estado de São Paulo. “Qualidade do ar no estado de São Paulo 2017.” CETESB, 2018. https://cetesb.sp.gov.br/ar/wp-content/uploads/sites/28/2018/05/relatorio-qualidade-ar-2017.pdf (accessed Jan. 30, 2019).

[28] Universidade de São Paulo. Instituto de Astronomia Geofísica e Ciências Atmosféricas, Boletim Climatológico Anual da Estação Meteorológica do IAG/USP”. IAG, 2017. [Online]. Available: http://www.estacao.iag.usp.br/Boletins/ 2017.pdf

[29] J. A. Marengo, L. M. Alves, T. Ambrizzi, A. Young, N. J. C. Barreto, and A. M. Ramos, "Trends in extreme rainfall and hydrogeometeorological disasters in the Metropolitan Area of São Paulo: a review," Ann. N. Y. Acad. Sci., vol. 1472, no. 1, pp. 1-16, 2020, http://dx.doi.org/10.1111/nyas.14307.

[30] M. Balzani, F. Maietti, and B. M. Kühl, "Point cloud analysis for conservation and enhancement of modernist architecture," Int. Arch. Photogramm. Remote Sens. Spatial Inf. Sci., vol. XLII-2/W3, pp. 71-77, 2017. http://dx.doi.org/10.5194/isprs-archives-XLII-2-W371-2017.

[31] Associação Brasileira de Normas Técnicas, Concreto - Extração, Preparo, Ensaio e Análise de Testemunhos de Estruturas de Concreto - Parte 1: Resistência à Compressão Axial, NBR 7680-1, 2015.

[32] V. A. Quarcioni, "Reconstituição de traço de argamassas simples e mistas de cimento Portland e cal hidratada: atualização do método do IPT,” M.S. thesis, Esc. Politéc., Univ. São Paulo, São Paulo, 1998.

[33] Instituto de Pesquisas Tecnológicas, Método Reconstituição do Traço do Concreto (Boletim 25). São Paulo: IPT, 1940, pp. 75-84. 
[34] A. Araujo and Z. Panossian, "Inspeção rotineira de estruturas de concreto armado expostas a atmosferas agressivas," Techne, vol. 19, pp. 58-64, 2011.

[35] Deutsches Institut fur Normung, Products and Systems for the Protection and Repair of Concrete Structures - Test Methods Determination of Carbonation Depth in Hardened Concrete by the Phenolphthalein Method, DIN EN 14630, 2007,10 p.

[36] A. Araujo, Z. Panossian, T. G. Rosa, and M. C. Braga, "Comportamento eletroquímico do aço-carbono em concreto: potencial de eletrodo e densidade de corrente elétrica," Téchne, no. 247, pp. 29-39, 2017.

[37] E. C. S. Thomaz. "Notas de aula: concreto: traços - fabricação - 1967 - eng. Abílio A. Caldas Branco.” http://aquarius.ime.eb.br/ webde2/prof/ethomaz/cimentos_concretos/pad_cimentos.htm (accessed Nov. 5, 2018).

[38] Nace International, Use of Reference Electrodes for Atmospherically Exposed Reinforced Concrete Structures (Publication 11100). Houston, 2000, 11 p.

[39] B. Elsener, C. Andrade, J. Gulikers, R. Polder, and M. Raupach, "RILEM TC 154-EMC Half-cell potential measurements - potential mapping on reinforced concrete structures," Mater. Struct., vol. 36, no. 7, pp. 461-471, 2003., http://dx.doi.org/10.1007/BF02481526.

[40] C. Andrade and C. Alonso, "RILEM TC 154-EMC Test methods for on-site corrosion rate measurement of steel reinforcement in concrete by means of the polarization resistance method," Mater. Struct., vol. 37, no. 11, pp. 623-643, 2004.

[41] G. Crevello, N. Hudson, and P. Noyce, "Corrosion condition evaluations of historic concrete icons," Case Stud. Constr. Mater., vol. 2, pp. 2-10, 2015., http://dx.doi.org/10.1016/j.cscm.2014.12.005.

[42] S. J. Meier and F. H. Wittmann, "Water repellent surface impregnation of concrete: guidelines and recommendations," in ASMES Int. Workshop - Basic Research on Concrete and Applications Proc., W. Folker H. and M. Olivier, Eds., Germany: Aedificatio Publishers Freiburg, 2011, pp. 49-66. http://dx.doi.org/10.1515/rbm-2011-6476.

[43] K. Tuuti, Corrosion Steel in Concrete. Swedish: Cement and Concrete Research Institute, 1982, 469 p.

[44] L. Bertolini, "Steel corrosion and service life of reinforced concrete structures," Struct. Infrastruct. Eng., vol. 4, no. 2, pp. 123-137, 2008, http://dx.doi.org/10.1080/15732470601155490.

[45] British Standards Institution, Products and Systems for the Protection and Repair of Concrete Structures - Definitions, Requirements, Quality Control and Evaluation of Conformity - Part 9: General Principles for the Use of Products and Systems, BS EN 1504-9, 2008, p. 32.

[46] P. E. Gaudette, H. J. Hunderman, and D. Slaton, "The repair of Mies van der Rohe's Promontory Apartment Building, Chicago: a multi-phased approach," in Concrete: Building Pathology, S. MacDonald, Ed., Oxford: Blackwell Science Ltd., 2003, pp. $269-281$.

[47] S. MacDonald, Ed., "University of Sussex: developing repair methods for the listed buildings," in Concrete: Building Pathology. Oxford: Blackwell Science Ltd., 2003, pp. 285-288.

[48] D. Slaton, P. E. Gaudette, and D. Patterson, "Morse and Ezra Stiles Colleges Yale University, New Haven, Connecticut," in International Specialist Committee/Technology Dossier 14 - Concrete and Modernism: Technology and Conservation, T. Prudon and K. Normandin, Eds., New York: Docomomo, 2018, pp. 32-37.

Author contributions: CAO: conceptualization, methodology, data collection, formal analysis, writing, supervision; AA e TRSS: conceptualization, methodology, data collection, formal analysis and writing.

Editors: Edna Possan, José Luiz Antunes de Oliveira e Sousa, Guilherme Aris Parsekian. 